\title{
Medical Waste Management in Korea's COVID-19 Response
}

\author{
Kim Jun ho ${ }^{1, *}$, Kim Soon-ok ${ }^{1}$, Lee Seong-han ${ }^{1}$, Lee Yun-jin ${ }^{1}$, Kim Ryunghwa ${ }^{1}$ \\ ${ }^{1}$ Waste information management division, Korea Environment Corporation, Incheon, South Korea \\ *Corresponding author. Email: Kjh9601@keco.or.kr
}

\begin{abstract}
Medical waste is an infection hazard for humans and requires management according to stricter standards than other types of waste. In the current COVID-19 pandemic, medical waste management to the strictest of standards must take place. Since 2008, real-time medical waste management systems using radio-frequency identification (RFID) technology have been developed, installed, and operated in Korea. To date, Korea is the only country in the world to have implemented this technology. The Korean government has also implemented a crisis management model designed for preventing the spread of COVID-19 and as an effective response to the pandemic. The three components of this model are: drive-thru and walk-thru screening; operation of community treatment centers for the treatment of mild cases; and operation of temporary living facilities for the selfquarantining of people entering Korea from abroad. Since the early stages of the pandemic, the Korean Ministry of Environment has been implementing special management measures for maximum safety in the management of the medical waste resulting from "K-quarantine" activities. A key aspect of these special management measures is the same-day discharge, transport, and incineration of the medical waste produced by COVID-19 patients.
\end{abstract}

Keywords: Medical waste, COVID-19, RFID, special management, measures

\section{INTRODUCTION}

In the current pandemic, the entire world is going through a health and economic crisis. Medical system failures are being pronounced in developing countries, even where the COVID-19 death toll is on a sharp incline.

The first case of COVID-19 in Korea was a woman entering Korea from Wuhan, China, who was identified on January 20, 2020. Following the identification of a fourth case on the 27th day of the same month, the Korean government raised the national crisis alert level from "Alert" to "Warning." Around a month after this change was made, a mass infection took place in the city of Daegu in Northern Gyeongsang Province. The national crisis alert level has since been elevated to "Severe," where it presently remains.

Still, unlike a number of other countries left incapacitated by the pandemic, Korean society remains functional in that everyday activity has continued to take place, albeit hindered by quarantine requirements. This has been enabled by the timely implementation of an extensive testing and diagnosis system.

The effectiveness of the COVID-19 response lies in the prevention of its spread through quick testing and tracing. Of equal importance is the safe management of the medical waste generated in this process.

The medical waste produced by COVID-19 patients is an infection hazard during its discharge, transport, and processing, and it must be managed with special attention. Medical waste has always been managed according to stricter standards than other types of waste. However, the current pandemic requires the management standards to be even further strengthened and backed by policies. Notable aspects of Korea's COVID-19 response are examined below. 


\section{KOREA'S MEDICAL WASTE MANAGEMENT SYSTEM AND TECHNOLOGY}

In Korea, medical waste, based on factors which include its infectiousness and harmfulness, is divided into the seven categories of "quarantine," "tissues" (recyclable placentas included), "bloodcontaminated," "pathological," “injurious," "biochemical," and "general medical waste" and is managed accordingly. Secondary infection during medical waste handling, i.e., during its discharge, transport, and processing, is prevented by discharging the medical waste in a medical waste container and transporting it by a suitable transport vehicle to a medical waste incineration facility to be safely processed.

Set storage durations are applied to the discharge, transport, and processing of medical waste by type, to minimize the chances of infection from microbial propagation.

Table 1. Mode and duration of the storage of medical waste by type

\begin{tabular}{|c|c|c|}
\hline Waste Type & $\begin{array}{l}\text { Container } \\
\text { Type }\end{array}$ & Storage Period \\
\hline Quarantine & $\begin{array}{l}\text { Plastic } \\
\text { container }\end{array}$ & $\begin{array}{c}\text { Discharge: } 7 \text { days } \\
\text { Transportation and } \\
\text { incineration: } 2 \text { days } \\
\text { each }\end{array}$ \\
\hline Tissues & $\begin{array}{c}\text { Plastic } \\
\text { container }\end{array}$ & $\begin{array}{l}\text { Discharge: } 15 \text { days } \\
\text { Transportation: } 5 \\
\text { days, incineration: } 2 \\
\text { days }\end{array}$ \\
\hline Injurious & $\begin{array}{c}\text { Plastic } \\
\text { container }\end{array}$ & $\begin{array}{c}\text { Discharge: } 30 \text { days } \\
\text { Transportation and } \\
\text { incineration: } 5 \text { days } \\
\text { each }\end{array}$ \\
\hline $\begin{array}{c}\text { Blood- } \\
\text { contaminated, } \\
\text { Biochemical } \\
\text { Pathological } \\
\end{array}$ & Liquid: & $\begin{array}{c}\text { Discharge: } 15 \text { days } \\
\text { Transportation and } \\
\text { incineration: } 5 \text { days } \\
\text { each }\end{array}$ \\
\hline $\begin{array}{l}\text { General } \\
\text { Medical } \\
\text { Waste }\end{array}$ & $\begin{array}{l}\text { Plastic } \\
\text { Solid: } \\
\text { Corrugated } \\
\text { cardboard }\end{array}$ & $\begin{array}{c}\text { Discharge: } 15 \text { days } \\
\text { (30 days if } \\
\text { refrigerated) } \\
\text { Transportation and } \\
\text { incineration: } 5 \text { days } \\
\text { each }\end{array}$ \\
\hline
\end{tabular}

In Korea, an RFID medical waste management system, which enables the real-time management of all processes involved in the discharge, transport, and processing of medical waste, has been in use since 2008
All entities engaged in the discharge, transport, and processing of medical waste in Korea must use the RFID medical waste management system. Today, some 90,000 dischargers, 210 transporters, and 14 incinerators are using RFID medical waste management systems for real-time updates of medical waste discharge, transport, and processing details.

With an RFID medical waste management system, an RFID tag is attached to a medical waste container and is read by an RFID reader for real-time updates of changes to the medical waste handling status. The RFID medical waste management system used in Korea enables the real-time management of medical waste discharge, transport, and processing, and is the only one of its kind in the world.

The components of the RFID medical waste management system are an RFID tag, a fixed or portable RFID tag reader, and an antenna for the fixed RFID tag readers.

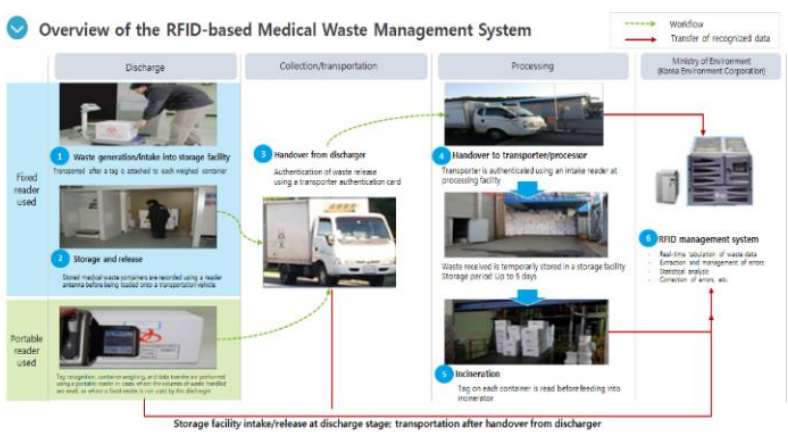

Figure 1. RFID-based Medical Waste Management system

Networking of Related Entities for the COVID-19 Special Management Code (approx. 2 days

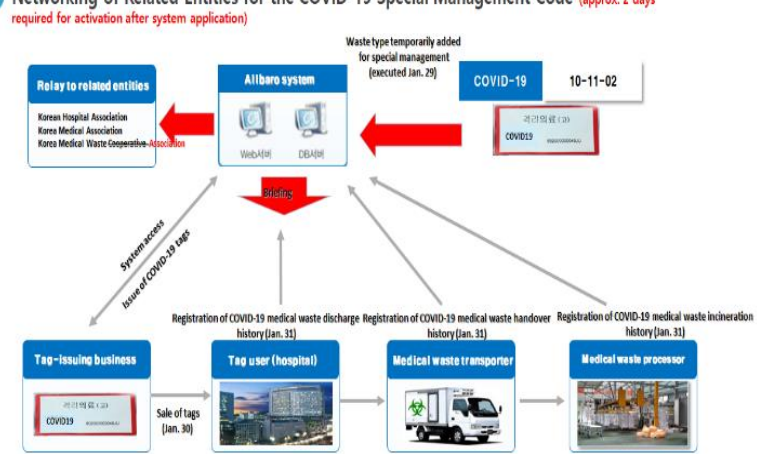

Figure 2. The components involved are RFID tags, RFID readers (fixed or portable), and tag issuers

\section{COVID-19 MEDICAL WASTE SPECIAL MANAGEMENT MEASURES}

Following the elevation of the national crisis alert level to "Warning" on January 27, 2020, the Ministry of Environment implemented special management 
measures for the safe processing of the medical waste produced by COVID-19 patients on January 29.

The essence of these special management measures involved the discharge, transport, and incineration of COVID-19 medical waste on the day of its production. In addition, a report-compiling headquarters was formed for the systematic monitoring of daily developments.

The Korea Environment Corporation, as the operator of the RFID medical waste management system, executed a functional upgrade in line with the special management measures of the Ministry of Environment for an effective COVID-19 response.

There were two aspects to this functional upgrade. First, "COVID-19 special management codes" were created and supplied for immediate application in frontline environments, for the management of COVID-19 medical waste separately from the 7 existing categories of medical waste.

Second, a change was made in the statistical computations for the reporting of daily developments. While statistical computations had been performed for each discharger, the upgrade enabled statistical computations by types of medical waste. This has cut down the time spent on statistical computations to one-fifth of what had been before.

Table 2. Monitoring and daily reporting of COVID-19 medical waste generation at special management facilities

[Unit : 1 entity, ton]

\begin{tabular}{|l|r|r|r|r|}
\hline & \multicolumn{1}{|c|}{$\begin{array}{c}\text { Dischar } \\
\text { ger }\end{array}$} & \multicolumn{1}{c|}{$\begin{array}{c}\text { Generat } \\
\text { ed }\end{array}$} & \multicolumn{1}{c|}{$\begin{array}{c}\text { Transpor } \\
\text { ted }\end{array}$} & \multicolumn{1}{c|}{$\begin{array}{c}\text { Incinera } \\
\text { ted }\end{array}$} \\
\hline $\begin{array}{l}\text { Tot } \\
\text { al }\end{array}$ & 915 & 17,585 & 17,585 & 17,550 \\
\hline $\begin{array}{l}\text { COVI } \\
\text { D19 }\end{array}$ & 895 & 14,659 & 14,659 & 14,650 \\
\hline Misc. & 169 & 2,926 & 2,926 & 2,900 \\
\hline $\begin{array}{l}\text { Daily } \\
\text { amount }\end{array}$ & 269 & 105 & 105 & 94 \\
\hline $\begin{array}{l}\text { COVI } \\
\text { D19 }\end{array}$ & 257 & 89 & 89 & 83 \\
\hline Misc. & 41 & 16 & 16 & 11 \\
\hline
\end{tabular}

Statistics produced after the upgrade indicate that 14,659 tons of COVID-19 medical waste were produced and, as per the requirement for same-day incineration, 14,650 tons of waste were incinerated as of July 23, 2021.

The statistics also indicated that 2,926 tons of medical waste in the category of "other" were produced, primarily at the temporary living facilities.
The collected statistics have enabled an analysis of the conditions of the medical waste processing infrastructure and workloads of the transporters during the current pandemic. Such an analysis has been referenced in the formation of government policies on the COVID-19 response.

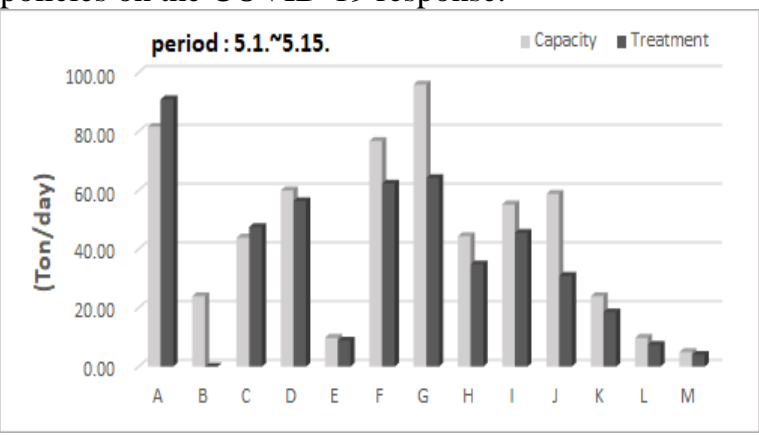

Figure 3. Overview of incineration at medical waste incineration facilities

Post-upgrade statistics played an important role in one particular development during the early stages of the pandemic: an incineration supplier located in an area of Seoul where a concentration of cases occurred was overloaded with COVID-19 medical waste targeted for incineration. Knowledge of this development was enabled by the post-upgrade statistics, and advanced measures for diverting these loads to other incineration suppliers were implemented accordingly.

\section{MEDICAL WASTE MANAGEMENT AT COMMUNITY TREATMENT CENTERS AND TEMPORARY LIVING FACILITIES}

COVID-19 Prevention Facilities. In Korea, various means of response were implemented in the early stages of COVID-19. This has allowed the pandemic to be controlled effectively on a national scale.

The first of these means was polymerase chain reaction (PCR) testing in a drive-thru or walk-thru setting. This was designed to prevent infections during sample collection and to enable fast testing, as the drive-thru/walk-thru PCR testing facilities enabled large numbers of Koreans to get tested in an astonishingly short period of time, and this played a pivotal role in curtailing community transmissions by identifying asymptomatic patients in local communities.

The second means was community treatment centers. The first community treatment centers were set up in the early stages of the pandemic in Daegu, 
where a mass infection had occurred, for the treatment of mild cases.

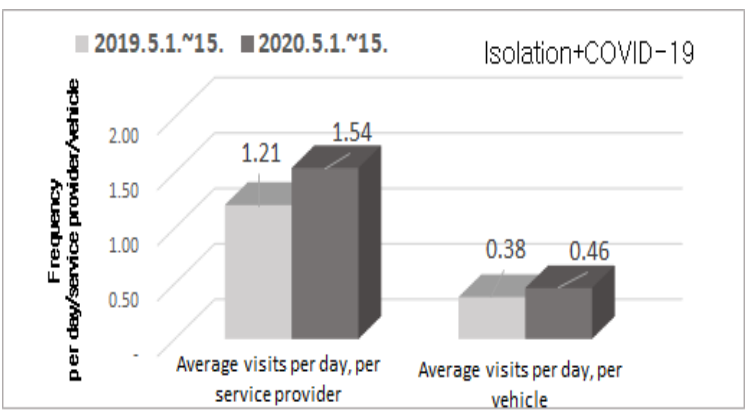

Figure 4. Overview of change in the intensity of work performed by transportation service providers

This allowed the state-designated hospitals to treat severe cases while mild cases were distributed among community treatment centers for the stability of local health systems.

A number of community treatment centers are still in operation, primarily in the locations affected by community transmissions.

The third means was temporary living facilities for the self-quarantining of people entering Korea from abroad. These facilities were initially set up for the self-quarantining of Koreans returning to Korea after being stranded overseas, in locations such as China and Europe in the early stages of the pandemic.

The temporary living facilities are now also being used by seamen entering Korea from overseas.

A person admitted to a temporary living facility for self-quarantining is required to stay alone in a room for 14 days. Living essentials are provided during the 14-day period. Other items needed can be ordered online, or received by post from the person's family members.

The admitted persons are provided with a thermometer for daily temperature checks, hand sanitizer, disinfectant, masks, and medical waste bags.

An admitted person who is confirmed as a COVID-19 patient during the self-quarantine period must discharge all items from their room in a medical waste bag, for processing as COVID-19 medical waste.

Medical Waste Management at Community Treatment Centers and Temporary Living Facilities. Safety is the top priority in waste management at the temporary living facilities. All waste produced at the temporary living facilities is incinerated.
With the exception of the everyday waste produced by medical personnel, the waste produced in all areas of a community treatment center is managed as COVID-19 medical waste. All protective clothing worn by medical personnel after coming in contact with patients in a community treatment center is also managed as COVID-19 medical waste.

As a negative PCR test result must be obtained before admission to a temporary living facility, the waste produced at a temporary living facility is managed as industrial waste, not medical waste; however, waste produced in a "red zone," which is a designated area where the admitted persons stand by for a sample test, is managed as general medical waste. If an admitted person develops symptoms or tests positive during the period of admission, all items used by that person in their room, including bedding, shaving equipment, toothbrushes, books, and footwear, are managed as COVID-19 medical waste and disinfection of the room takes place.

Instructions on the discharge of waste are provided in different languages, to cater to the admitted persons of various linguistic backgrounds.

The admitted persons must place the safely packaged waste outside their rooms at a set collection time (once a day). Sanitation workers then disinfect the rooms and hallways before moving the collected waste to a designated waste storage facility.

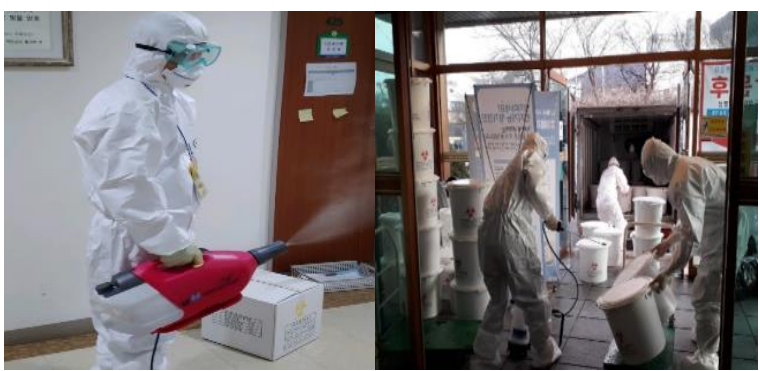

Figure 5. Processing of medical waste discharged from facilities

Sanitation workers wear full personal protective equipment during the waste collection. The used personal protective equipment is managed as general medical waste.

Persons admitted to a temporary living facility are tested at the end of their self-quarantine period and are only released if a negative test is returned. This prevents community transmissions.

\section{CONCLUSIONS}

In the COVID-19 response, waste management is as important as quarantining, testing, and treatment. 
As such, COVID-19 medical waste management policies and technology that meets the highest of standards in the world are being implemented in Korea.

Every country is fighting the pandemic, but the effectiveness of the response is decided by the capacity of a given country. In some countries, medical waste management is not receiving the policies and treatment it deserves. Medical waste management systems and an effective infrastructure take time to build. As the post-pandemic world looms, every country must make efforts to optimize its medical waste management.

\section{REFERENCES}

[1] Korea Disease Control and Prevention Agency (Jan. 2020-present), COVID-19 Developments Report.

[2] Ministry of Environment (Jan. 2020), COVID19 Medical Waste Special Management Measures.

[3] Ministry of Environment (Feb. 2020), COVID19 Medical Waste Special Management Measures: Revision 1.

[4] Ministry of Environment (Mar. 2020), COVID19 Medical Waste Special Management Measures: Revision 2. 